\title{
THE NATIONAL SCIENCE FOUNDATION
}

\begin{abstract}
$T$ HE eleventh annual report of the National Science Foundation *, covering the year ended June 30,1961 , records grants for research totalling 69 million dollars, compared with 62 million dollars in 1960, requests for support increasing, however, much more rapidly, from 163 million dollars to 256 million dollars. Some 15 million dollars were also made available for research facilities, including 8.5 million dollars for construction and modernization of graduate research laboratories and a further 8 million dollars were awarded to the three national research centres: the National Radio Astronomy Observatory; the Kitt Peak National Observatory; and the National Centre for Atmospheric Research. In the biological and medical sciences support has been afforded in molecular, genetic, developmental, meta. bolic, regulatory, environmental and systematic biology and psychology. In these fields significant research developments noted in the report are: the determination of the amino-acid sequence of tobacco mosaic virus protein; the successful photographing of unbroken deoxyribonucleic acid; the synthesis of a substance containing 23 amino-acid groups with all the biological properties of adrenocorticotropic hormone; and of luciferan, the light-emitting compound in fireflies. It has also been established that nucleotides play a key part in cell differentiation, that cobalt is essential for the growth of soya bean plants under mbiotic conditions and for the growth of the symbiotic bacteria, that even a few alder trees can play a major part in providing nutrient material for lakes and leaf-fall from alders contains four times as much nitrogen as defoliation from other species, and that carotenoids protect the plant cell from chlorophyll-catalysed photoxidation damage, while further information has been obtained on the structure and function of mitochondria.

In the mathematical, physical and engineering sciences, Project Mohole, a joint venture with the U.S. National Academy of Sciences, was probably the

* National Science Foundation. Eleventh Annual Report for the Fiseal Year ended Juno 30, 1961. Pp, Xxxi+325. (Washington, 319 of this issue.)
\end{abstract}

most spectacular project supported by the Foundation during the year, and this deep penetration of the Earth's sub-oceanic crust has established the feasibility of deep-ocean drilling (Nature, 184, 140 1959).

Extra-galactic cosmic particles with an energy 500 million times that generated by the largest accelerator were detected during the year, and an atomic hydrogen maser constructed with an accuracy 100,000 times that of the best time standard yet known. Quantization of magnetic flux in super conductors was confirmed and 17 new exploding supernovæ were discovered during the year.

For the programmes of its Division of Scientific Personnel and Education, the Foundation allocated some 70 million dollars during the year. The 4,196 fellowship awards, totalling $14 \cdot 1$ million dollars, brought the totals since the inception of the programme in 1952 to some 17,000 Fellows and 57 million dollars. The Foundation also supported 771 institute programmes during the year. Of those, 396 were summer institutes attended by 21,000 teachers; 33 were academic year institutes, attended by 1,534 teachers of seience and mathematics; 191 were in service institutes attended by 8,900 secondary school teachers, with a further 13 institutes for 400 participants from elementary schools, all on a parttime basis. Besides containing programmes for secondary schools, such as visits from outstanding scientists and travelling science libraries, and a programme designed to develop co-operation between colleges and secondary schools in improving the quality of education in the sciences, the Division promotes programmes for advanced education in science, including supplementary training for science teachers and studies to improve the extent of courses in science and engineering, the design and develop. ment of prototypes of new equipment for teaching science. For this 57 grants were awarded, and since 1958 the Foundation has awarded grants totalling 4 million dollars to the School Mathematics Study Group for projects aimod at improving the towching of mathomatics.

\section{TECHNOLOGICAL IMPORTANCE OF INDUSTRIAL DIAMOND}

$\mathrm{T}$ HE name 'diamond' conjures up to many only beautiful costly gemstones, yet diamond is a technological hard material of the greatest importance; indeed, it can be now regarded technically as a fundamental strategic raw material. Of the annual world output of mined diamond, which is some 25 million carats, that is, 5 tons, only 1 ton is used for gemstones, the remaining 4 tons being eagerly consumed in industry largely as a hard abrasive or a cutting material. This 4 tons of crystalline matter, as raw material alone, fetches something like $£ 20$ million, and its extraction involves the formidable problem of sorting from something like 125 million tons of diamondiferous ore, the diamond being very thinly distributed indeed.

The technological importance of diamond lies in its immense hardness, which surpasses that of al other materials. The uses of diamond are growing rapidly in two broad categories: (1) single individual diamonds; (2) crushed grit. The range of use is enormous, from lathe-cutting tools to gramophone needles, from the truing and shaping of precision grinding wheels to tho cutting and drilling of glass. Then again diamond rock-saws, diamond rock-drills, diamond wire-drawing dies, indeed even diamond microtome cutting-knives, all these are but a few of the multifarious industrial uses of singly mounted diamonds.

The strategic importance of the material, evon to the military as well as to industry, is immediately apparent when one considers, for example, such aspects as mass-produced engines, automobiles, ete; for many basic components are rapidly shaped by accurately rnade silicon-carbide grinders of precise form and dimension. But, of course, the grinders wear and they must be continually reshaped and trued, and 